\title{
Studenters oppfatninger av god og dårlig praksisveiledning i barnehagelærerutdanning
}

\author{
Kirsten S. Worum ${ }^{1 *}$, Cato R. P. Bjørndal ${ }^{1 *}$ \\ ${ }^{1}$ UiT - Norges arktiske universitet
}

\section{Sammendrag}

Formålet med artikkelen er å få innsikt i studenters oppfatninger av god og dårlig praksisveiledning i barnehagelærerutdanningen, noe som er avgjørende for å utvikle praksisveiledningens kvalitet. Studentperspektivet på praksisveiledningens kvalitet er lite fremtredende i nordisk forskning på barnehagelærerutdanning. Studien er basert på fire fokusgrupper, der studenter fra 1.-3. studieår i barnehagelæreutdanningen utveksler erfaringer og synspunkter på hva de oppfatter som god og mindre god praksisveiledning. Studentenes oppfatninger av kvalitet omfatter åtte aspekt; oppfølging av veilederen, veiledning tilpasset sitt behov, gode tilbakemeldinger, bli utfordret av veilederen, åpen dialog og gjensidig læring, veiledning sammen med andre men også alene, gode holdninger hos veilederen og godt samspill mellom praksis og campus. Funnene diskuteres i forhold til internasjonal forskning og diskursen mellom veiledningspedagogiske tradisjoner, og sees i lys av kvalitetsbegrepet $\mathrm{i}$ høyere utdanning med vekt på prosesskvalitet.

The purpose of this article is to gain insight into student-perceptions of supervision of practical training in kindergarten teacher-education. Today there is little Nordic research from the student-perspective on the quality of supervision of practical training in kindergartens. In this study students in their first, second, and third years of study, divided into four focus-groups, exchanged experiences and views on what they perceive as good and bad practical supervision. Students' perceptions of quality include; follow-up from the practical-training supervisor, supervision adapted to their needs, good feedback, being challenged by the supervisor, open dialogue and mutual learning, supervision along with others but also alone, good attitudes of the mentor, and good interaction between the practical placement and campus. The findings are discussed in relation to international research and the discourse between central Nordic schools of supervision. Findings are also seen in light of the concept of quality in higher education.

Nøkkelord: Kvalitet; student; perspektiv; erfaring; veiledningspedagogikk; fokusgruppe

\section{* Kontakt:}

Kirsten S. Worum

HSL-FAK, ILP

UiT - Norges arktiske universitet

E-post: kirsten.worum@uit.no
Cato R. P. Bjørndal

HSL-FAK, ILP

UiT - Norges arktiske universitet

E-post: cato.bjorndal@uit.no

Fagfellevurdert artikkel. Publisert: 20.12.2018

Nordisk tidsskrift i veiledningspedagogikk @ 2018 Kirsten S. Worum og Cato R. P. Bjørndal This is an open access article distributed under the terms of the Creative Commons Attribution License DOI: http://dx.doi.org/10.15845/ntvp.v3i1.1578 


\section{Betydningen av innsikt i barnehagestudenters oppfatninger av praksisveiledningens kvalitet}

Denne artikkelen er basert på en fokusgruppestudie med formål om å få innsikt i barnehagelærerstudenters perspektiv på kvalitet i praksisveiledning, og forskningsspørsmålet er: Hvordan oppfatter studenter $i$ barnehagelærerutdanning god og dårlig kvalitet $i$ praksisveiledning? Det pekes stadig på at det er forsket for lite på praksisopplæring og praksisveiledning i barnehagelærerutdanning, spesielt i Norden. Blant annet hevdes det at en har for lite kunnskap om hvordan studentene opplever praksis (f.eks. Oberhuemer, 2015; Ødegaard \& Økland, 2015; Bjerkestrand et al., 2016; Kunnskapsdepartementet, 2017).

Innsikt i studentenes perspektiv er avgjørende for å utvikle praksisdelen av barnehagelærerutdanning. En viktig begrunnelse er at studenters oppfatninger av god kvalitet i praksisveiledning ikke nødvendigvis korresponderer med praksisveilederes forståelse. Dette kan skape store utfordringer for samarbeidet og studentene kan oppfatte mange sider ved praksisveiledningen som problematisk ( $f$. eks. Rouse et al., 2012). Det er «nødvendig for lærerutdanningene å forstå studentenes læreprosesser i praksis for å kunne følge opp med gode tiltak» ( $\varnothing$ degaard \& $\varnothing$ kland, 2015, s. 24). Betydningen av studentperspektivet fremheves også i kvalitetsmeldingen for høyere utdanning i Norge, der det pekes på at studentene må bli en del av en kultur der en tar felles ansvar for å utvikle kvalitet (Kunnskapsdepartementet, 2017). Det kan imidlertid være vanskelig for studenter å bli hørt i praksisveiledningen dersom de stiller spørsmål ved oppfatninger som praksisveilederen tar for gitt (Søndenå, 2004).

Praksis og praksisveiledning i barnehagelærerutdanningen har i senere år fått en sterkere posisjon i Norge, Sverige og Danmark (Oberhuemer, 2015), selv om det også her etterlyses mer ressurser (Juul, 2015). I en nylig avsluttet evaluering av barnehagelærerutdanningen i Norge går det fram at alle institusjonene har utfordringer knyttet til praksisopplæringen (Bjerkestrand et al., 2017, s. 42). Spesielt fremhever studentene «at det er store sprik i krava som praksislærarane stiller til dei og etterlyser meir kvalifisert vurdering av arbeidskrava sine» (Bjerkestrand et al., 2017, s. 46).

Et sentralt fokus i nasjonale og internasjonale bestrebelsene på å forbedre praksisopplæringen har vært å styrke praksisveiledernes veiledningskompetanse (Oberhumer, 2015; Bjerkestrand et al., 2017, s. 43). Praksisveiledernes formelle veiledningskompetanse varierer sterkt og utdanningsinstitusjonene oppfordres derfor til å styrke praksisveiledernes veiledningskvalifikasjoner (Kunnskapsdepartementet, 2017). Praksisveilederne i Norge har fått ny status blant annet gjennom kravet om 15 stp. veilederutdanning (Forskrift om rammeplan for barnehagelæreutdanning, 2012). Hva som mer konkret kjennetegner god praksisveiledning har fătt mindre oppmerksomhet. Dette kan skyldes at de mer generelle oppfatningene av hva god kvalitet i høyere utdanning er, spriker i mange retninger og preges av ansattes ulike interesser (Elken, 2007).

Veiledningsbegrepet kritiseres tidvis for å anvendes med begrenset presisjon, og ofte med et idealistisk innhold (Bjørndal, 2008). I Norge omtales dessuten praksisveiledning vekselvis med delvis overlappende termer som for eksempel praksisopplæring, praksisperioder eller praksis. Praksisveiledning kan på den ene siden defineres snevert, som praksisveilederens interaksjon med en eller flere studenter igjennom praksisperioden. Nordisk veiledningspedagogikk kan hevdes å bære preg av dette, spesielt idet man særlig har fokusert på den avgrensede veiledningssamtalen mellom student(er) og veileder (Bjørndal, 2008). Hva som forstås som (praksis-) veiledning vil også variere noe avhengig av hvilken veiledningstradisjon veiledningen er preget av (jf. senere omtale av veiledningstradisjoner). Praksisveiledning kan imidlertid også forstås videre, som studenters veiledede praksis. Studentenes erfaringer med kvalitet i praksisveiledning vil bredt forstått ikke bare omfatte den direkte interaksjonen med veilederen, men som prosesskvalitet i vid forstand: Dette kan for eksempel omfatte interaksjon og relasjoner mellom veileder og studenter og andre aktører på skoler og campus - før, underveis og etter praksisperioden (Hatlevik, 2016). Erfaringene kan ikke minst henge sammen med veilederens (veilednings-)kompetanse. 
Når studentene i denne undersøkelsen har uttalt seg om god og dårlig praksisveiledning, har de snakket ut fra en slik utvidet forståelse av hva praksisveiledning er. Den induktive tematiske analysen som presenteres i artikkelen har rimelig nok også utgangspunkt i studentenes vide forståelse av praksisveiledning.

\section{Kvalitetsbegrepet i høyere utdanning}

Kvalitetsbegrepet anvendes både for styring og utvikling av høyere utdanning, og står blant annet sentralt i styringsdokumenter og andre offentlige dokumenter. I Kvalitetsmeldingen for høyere utdanning vektlegges konkrete forventninger til universitetene og høyskolenes eget arbeid med utdanningskvalitet (Kunnskapsdepartementet, 2017). Et kjennetegn på god kvalitet som ofte fremheves i lærerutdanningen er praksisveilederens erfaring og veiledningskompetanse (Forskrift om rammeplan for barnehagelæreutdanning, 2012, s. 13). Det forventes at universitetene og høyskolene skal styrke kunnskapsgrunnlaget om kvalitet i høyere utdanning gjennom mer forskning på egen utdanningsvirksomhet. Utdanningskvalitet hevdes å bli til i møtet mellom studenter og undervisere, mellom undervisere, og studentene imellom, og her er det behov for endring for å løfte utdanningskvaliteten (Kunnskapsdepartementet, 2017, s. 21).

Kvalitet forstås ulikt i høyere utdanning (Kunnskapsdepartementet, 2017) og det er vanskelig å finne en enhetlig definisjon (Harvey, 2006; Wittek \& Kvernbekk, 2011; Dahler-Larsen, 2013). Dette begrunnes med at kvalitetsbegrepet rommer mange dimensjoner og perspektiver. Kvalitet betyr forskjellige ting, er knyttet til ulike oppfatninger, interesser og ulike kontekster i utdanningen (Dahler-Larsen, 2013, s.34). I de nordiske landene relateres kvalitet i barnehagelærerutdanningene i stor grad til retningslinjer i utdanningen (Roth, 2014). Samtidig råder en felles oppfatning om at kvalitetsbegrepet er relatert til prosesser (Harvey, 2006; Hatlevik, 2016; Wittek \& Kvernbekk, 2011). Prosesskvalitet i praksisopplæringen handler om relasjonen til campus, det som skjer før - og etter praksis, men også til relasjon mellom student og veileder, og om veileders veiledningskompetanse. Forskning på praksisopplæringen ved profesjonsutdanninger, innenfor både lærer-, helse- og sosialarbeiderutdanninger, avdekker at dette er felles for praksisopplæring på tvers av de ulike profesjonsutdanningene (Hatlevik, 2016, s. 200).

\section{Veiledningspedagogisk diskurs om kvalitet i praksisveiledning}

Til tross for begrenset forskning på praksisveiledning i nordisk barnehagelærerutdanning er det i de senere tiårene utgitt omfattende nordisk faglitteratur om praksisveiledning i ulike kontekster. Aspektene av kvalitet som vektlegges varierer og i litteraturen finnes en diskurs mellom veiledningstradisjoner som dels står i motsetning til hverandre (Bjørndal, 2008; Bjerkholt, 2017; Søndenå, 2004; 2007; Skagen, 2013; Worum, 2014). Noen sentrale trekk fremheves nedenfor.

Norsk og nordisk veiledningspedagogikk vokste særlig frem fra 1980-tallet gjennom Handal og Lauvås' kritikk av tradisjonell praksisveiledning, som spesielt tok avstand fra den tusenårige mesterlæretradisjonen. Handal og Lauvås kritiserte tradisjonell veiledning, og oppfattet spesielt at studentene kunne bli mer opptatt av strategisk tilpasning enn selvstendig utvikling. De utviklet isteden en strategi som skulle sikre studentenes personlige og yrkesmessige utvikling ved å nedtone veilederens vurderinger av studentens praksis. Isteden fokuserte de mer på studentens selvstendige refleksjon og vurderinger av praksis gjennom å bli bevisst og utvikle sin egen praksisteori. Handal og Lauvås' strategi, som er kalt Refleksjon over handling, har siden dominert i Norden (Skagen, 2013, s. 66). Strategien er sterkt påvirket av henholdsvis det Sokratiske dialogidealet og Carl R. Rogers' ikke-ledende terapi. Disse idealene peker mot noe ulike veiledningssamtaler: Det sokratiske dialogidealet innebærer en veileder som spesielt utfordrer gjennom krevende spørsmål og der partene er orientert mot felles søken etter sannhet (episteme) og ikke bare meninger (doxa), mens Rogers' humanistiske dialogideal peker mot en veileder som særlig vektlegger empatisk lytting med formål om å understøtte enkeltindividets vekst (Bjørndal, 2008). 
På nittitallet kom Kvale m.fl. (1999) med et sterkt forsvar for mesterlæren. Mesterlærens kvalitet ses særlig ved at den er situert $\mathrm{i}$ arbeidssituasjonen der en gradvis deltar og tilegner seg identitet $\mathrm{i}$ et praksisfellesskap, der en lærer gjennom konkret handling, gjennom observasjon, imitasjon og korrigerende tilbakemeldinger. En lærer gjennom handling der veiledning ut $\varnothing v e s$ mens lærlingen prøver å mestre yrkesutfordringene vedkommende står overfor.

Refleksjon-over-handling-tradisjonen er kritisert for å fokusere for ensidig på enkeltindividets læring og for lite fokus på den sosiale siden av læring (se f.eks. Søndenå, 2004). Videre har det vokst frem en stadig sterkere tradisjon for veiledning i grupper med to eller flere studenter, som forankres i sosiokulturell læringsteori. Mens Handal og Lauvås fokuserte på begrunnelser for egne handlinger vektlegger denne tradisjonen konstruksjon av ny forståelse gjennom gjensidig deling av mening, synspunkter, erfaringer og normer (Gjems, 2007 s. 155). Denne tradisjonen preges i likhet med Refleksjon over handling av et ideal, der respekt, likeverdighet, deltakerstyring og problemorientering står sentralt. Senere publikasjoner refererer ikke minst til Bakhtins dialogiske teori og fremheving av den verdi flerstemmighet og «den Andre» kan ha for overskridende meningsskaping i praksisveiledning (Søndenå, 2004; Bjerkholt, 2017; Worum, 2014). Veilederen har her et særlig ansvar for at både egne og andres synspunkter, meninger, erfaringer og teoretiske perspektiver bidrar til å belyse og forstå problemstillingen (Worum, 2014). Videre hevdes det kritisk at veilederen i Refleksjon over handling-tradisjonen har ikke spesifikt ansvar for å bringe inn ny kunnskap eller egne synspunkter, men heller opprettholder teoretiske og praktiske tradisjoner gjennom fokus på individuelle refleksjonsprosesser (Søndenå, 2004; Worum, 2014).

En studie viser også at det innad i en lærerutdanning finnes ulike veiledningsdiskurser. Kunnskapssynet som lå til grunn for veiledning i praksisplanene var preget av en individorientert tilnærming i tråd med Handal og Lauvås sin veiledningsstrategi, mens veilederutdanningens bygde på et mer intersubjektivt kunnskapssyn, med vekt på kollektiv læring (Worum, 2016). Det er videre pekt på svakheter ved for ensidig fokus på refleksjon og dialog i veiledning. For eksempel kritiserer Skagen (2013) tendensen til å gå bort fra at studenten bør observere praksisveilederens praksis og at praksisveilederen på sitt beste kan være modell for studenten - noe som altså er et ideelt kjennetegn ved mesterlære.

Diskursen mellom ulike veiledningstradisjoner om hva som kjennetegner god praksisveiledning er stadig levende og mer kompleks enn trekkene som skisseres her. Det er imidlertid behov for flere empiriske bidrag i diskursen.

\section{Forskning på studenters oppfatninger av praksisveiledningens kvalitet $\mathbf{i}$ barnehagelærerutdanning}

I Norden er det lite forskning på barnehagestudenters perspektiv på praksisveiledningen. I Norge er det imidlertid i de senere år gjennomført flere studier av veiledning med nyutdannede barnehagelærere og utvikling av lærende barnehager ( Ødegård, 2011; Steinnes, 2014; Eik, 2014; Fimreite \& Foss $\varnothing y, 2018$ ). Eik (2014) finner eksempler på at nyutdannede barnehagelærere kan oppleve det som vanskelig å finne tema til veiledningssamtalene. Veileders st $\varnothing$ tte i veiledning hevdes også å ha liten betydning dersom veileder ikke utfordrer og stiller spørsmål ved veisøkernes oppfatninger, og i tillegg bidrar med egen kompetanse i veiledningen. Det hevdes også å være av stor betydning at nyutdannede får artikulert sine faglige begrunnelser og alternative forståelsesmåter og se disse i lys av veileders erfaringer. Studien viser dessuten at veilederutdanning har betydning for veisøkers utbytte av veiledning.

En undersøkelse av praksis i dansk barnehagelærerutdanning (Juul, 2015) viser at det er vanskelig å sette av nok ressurser, $\mathrm{i}$ form av tid til veiledning for studentene og tid til veilederutdanning for praksislærere. Studien viser at det også i Danmark er store variasjoner i praksisveiledernes veiledningskompetanse. En svensk studie undersøker hvordan barnehagelærerstudentene formes gjennom veiledningssamtaler med erfarne barnehagelærere i praksisperiodene Den viser at to rådende diskurser preger veiledningssamtalene, den ene er praksisorientert og den andre er teoribasert. Studien 
konkluderer med at det må utvikles en veiledningspraksis som unngår ensidig utvikling mot enten praksis eller teori, og i større grad bidrar til mangfold og flerstemmighet i veiledning (Hjort \& Pramling, 2014).

Flere studier fra ulike vestlige land har unders $\varnothing \mathrm{kt}$ barnehagestudenters oppfatninger av kvalitet i egen praksisveiledning. Syv brede, relaterte og delvis overlappende temaer trer frem som særlig sentrale:

God relasjon til veileder (1): Et av aspektene studenter vektlegger er betydningen av en god relasjon til, match eller kjemi med praksisveilederen (Caires et al., 2009; Moody, 2009; Schagen Johnson et al., 2017), og studentene ønsker en relasjon preget av gjensidig respekt og likeverd (Beck \& Kosnik, 2002; Turnbull, 2005).

Mulighet til pedagogisk selvstendighet (2): Studenter opplever også en viss pedagogisk selvstendighet i praksis som viktig og studenter kan oppleve dominerende, sterkt styrende veiledere eller konformitetspress som negativt (Han \& Damjanovic, 2014; McNay \& Graham, 2007; Turnbull, 2005). Studenter verdsetter i motsetning til dette frihet til å utvikle sin egen pedagogiske stil (Macy \& Squires, 2009; Moody, 2009; Rouse et al., 2012).

Opplevd støtte fra veileder (3): Studenter opplever også emosjonell og praktisk støtte fra veilederen igjennom praksisperioden som grunnleggende viktig (Beck \& Kosnik, 2002; Malderez, Hobson, Tracey, \& Kerr, 2007; Moody, 2009; Turnbull, 2005). I motsetning til dette omtales fraværende veiledere som et problem (Rouse et al., 2012).

Tilbakemelding fra veileder (4): Studenter ser tilbakemeldinger fra veileder som avgjørende for sin utvikling. De gir imidlertid svært variable beskrivelser av kvaliteten ved tilbakemeldingene de mottar (Beck \& Kosnik, 2002; Macy \& Squires 2009; Moody, 2009). Studenter verdsetter spesielt positive tilbakemeldinger, og tilbakemeldinger som er rettet mot utvikling av konkrete profesjonelle ferdigheter (Han \& Damjanovic, 2014; Moody, 2009; Turnbull, 2005). De vektlegger også tilbakemelding om problemer og utfordringer som fordrer refleksjon. Motsatt kan studenter oppfatte manglende og uklare tilbakemeldinger som svært negativt (Beck \& Kosnik, 2002; Moody, 2009; Turnbull, 2005; Ledoux et. al., 2008).

Tilpasning til studentenes ulike behov (5): Et gjentakende funn er også verdsetting av at veiledningen tilpasses ulike studenters nivå og behov (Field, 2002; Macy \& Squires, 2009; McCollum \& Catlett, 1997). Erfarne studenter legger for eksempel større vekt på muligheten til å styre selv og til selvvurdering av egen praksis (Field, 2002; Rouse et al., 2012). Studenter kan videre ønske å møte en bredde utfordringer og en arbeidsmengde som er tilpasset deres kapasitet (Beck \& Kosnik, 2002; Macy et al. 2009).

Veilederens øvrige egenskaper (6): I enkelte undersøkelser fremhever også studentene spesifikke egenskaper som ikke er omtalt i de øvrige temaene. For eksempel påpekes det at dårlige holdninger hos veileder kan være et alvorlig problem (Shahid \& Hussain, 2011), og at veilederens kompetanse til å veilede studenter og arbeide pedagogisk med barn kan oppfattes problematisk (Beck \& Kosnik, 2002; Rouse et al., 2012).

Verdsetting av parpraksis (7): Hoveddelen av undersøkelsene som er omtalt ovenfor omhandler erfaringer fra individuell praksisveiledning. Flere unders $\varnothing$ kelser av parpraksis indikerer imidlertid at slik praksis kan være høyt verdsatt av barnehagestudenter. For eksempel fremheves støtte, kollegialitet, bedre planlegging og gjennomføring av praksis, samt bedre analyse og refleksjon som positivt (Bullough et al., 2002; Kromrey \& Wynn, 1999; Walsh \& Elmslie, 2005). Videre kan parpraksis oppleves mindre stressende og mer motiverende (Campbell-Evans \& Maloney, 1997), selv om slik praksis også innebærer spesifikke utfordringer (Walsh \& Elmslie, 2005).

Praksisoppfølging av veileder fra campus nevnes også i noen undersøkelser. Tilbakemeldinger fra vedkommende kan være verdsatt, men denne delen av veiledningen kan være problematisk og det uttrykkes behov for en tydeligere rolle og koordinering mellom utdanningen på campus og praksissted (Han \& Damjanovic, 2014; Moody, 2009; Weasmer \& Woods, 2003).

De refererte unders $\varnothing$ kelsene gir samlet sett et bredspektret bilde av barnehagestudenters oppfatninger av kvalitet. Undersøkelsene bygger særlig på surveys og kvalitative intervjuer og dels deltakende observasjon. Ingen av undersøkelsene har anvendt fokusgrupper, slik denne unders $\varnothing$ kelsen gjør. 


\section{Datamateriale og metodisk tilnærming}

Formålet med undersøkelsen har vært å få innsikt i hvordan barnehagestudenter oppfatter praksisveiledningens kvalitet. Derfor ble fokusgrupper valgt som metode. Styrken ved slike åpne og ustrukturerte samtaler er at de kan gi rom for dynamisk meningsutveksling og rikholdige opplevelser (Barbour, 2007).

For at deltakerne skulle snakke mest mulig åpent ut fra sitt perspektiv ble det ikke benyttet intervjuguide. En enkel figur dannet utgangspunkt for fokusgruppesamtalene, med teksten «deres ulike synspunkter på kvalitet i praksisveiledning» i sentrum, og enkelte stikkord rundt som var mulig men ikke nødvendig å snakke om. Deltakerne ble oppfordret til å snakke fritt, utveksle erfaringer og meninger, og «cafesamtale» ble fremhevet som ideell metafor. To tilstedeværende forskere lyttet primært og stilte få spørsmål.

Datainnsamlingen ble gjennomført i løpet av ett kalenderår og artikkelens datasett bestod av fire fokusgruppesamtaler med 6-12 studenter (hver ca. 1,5 t). To av studentgruppene var i første studieår, én gruppe var fra andre studieår og den siste gruppen var fra tredje studieår. Deltakerne meldte seg frivillig etter invitasjoner før undervisning, i fellesarealer på campus samt på Facebook.

Samtalene ble transkribert og det ble gjennomført en systematisk induktiv tematisk analyse (Braun \& Clark, 2006). Braun og Clarks seksfasede analyseprosedyre ble fulgt: 1) gjøre seg kjent med data, 2) generere innledende koder, 3) søk etter temaer, 4) revidering av temaer, 5) definere temaer og 6) utarbeide analysetekst. Mer spesifikt fulgte fase 2 Charmaz' (2006) beskrivelse av åpen “line-by-line-opencoding", der uttalte aspekter ved kvalitet ble kodet linje for linje. Tolkninger av koder, temaer og deltemaer ble stadig sjekket opp mot og revidert i forhold til transskriptene. Parallelt med utviklingen av temaer leste en av forskerne transkriptene mer helhetlig, og stilte kritiske spørsmål som gjorde at sammenhengen mellom innholdet i transkripter og de genererte temaene stadig ble etterprøvd og justert.

Som del av analysearbeidet ble det utarbeidet et tematisk kart (Braun \& Clark, 2006), jf. figur 1. Forbindelsen mellom transskript, koder og endelige temaer eksemplifiseres i tabell 1 :

Tabell 1. Eksempel på «line-by-line-coding» fra transskript og forbindelsen til hovedtema og deltemaer.

\begin{tabular}{lll}
\hline $\begin{array}{l}\text { Transskript } \\
\text { Fokusgruppe } 3\end{array}$ & $\begin{array}{l}\text { Kode med referanse } \\
\text { (transkriptnr., linjenr.) }\end{array}$ & Generert hovedtema og deltemaer \\
$\begin{array}{l}\text { Inf: Jeg tenker at veileder er ærlig. Det har } \\
\text { lett for at man blir så forsiktig, alt er så }\end{array}$ & Tema 3: Få gode tilbakemeldinger fra \\
bra, du er så flink. Men det er jo ikke det & AERLIG TILBAKEMELDING 3,5 & - Deltema 3d: ÆErlige og kritiske \\
man lærer av. Man lærer av at «du må & LAERE AV INSTRUKTIV & tilbakemeldinger \\
gjøre mer sånn og sånn». & TILBAKEMELDING 3,7 & - Deltema 3b: Tydelige tilbakemeldinger
\end{tabular}

Analysen resulterte i åtte hovedtemaer (a-h i videre presentasjon), generert av 355 koder. $\emptyset$ vrige koder (87) inngikk ikke i temaer (18) eller i mindre utbredte temaer (69).

Et vitenskapsteoretisk skille går mellom henholdsvis erfaringsmessige og kritiske orienteringer $\mathrm{i}$ tematiske analyser (Braun \& Clarke, 2006). Denne artikkelen karakteriseres av førstnevnte orientering, idet hele forskningsdesignet primært rettes mot å bringe frem studentenes perspektiv, heller enn å problematisere eller forklare sammenhenger med større forhold. Nært relatert skilles det gjerne mellom induktive og deduktive tematiske tilnærminger. Undersøkelsens forskningsdesign er utpreget induktivt, idet både de beskrevne intervju- og analysemetodene innebærer at en systematisk bestreber seg på å innhente data fra studentenes perspektiv, uten å styre intervjuer og analyse ut fra et teoretisk rammeverk eller forutgående forståelse (Barbour, 2007; Braun \& Clarke, 2006). 


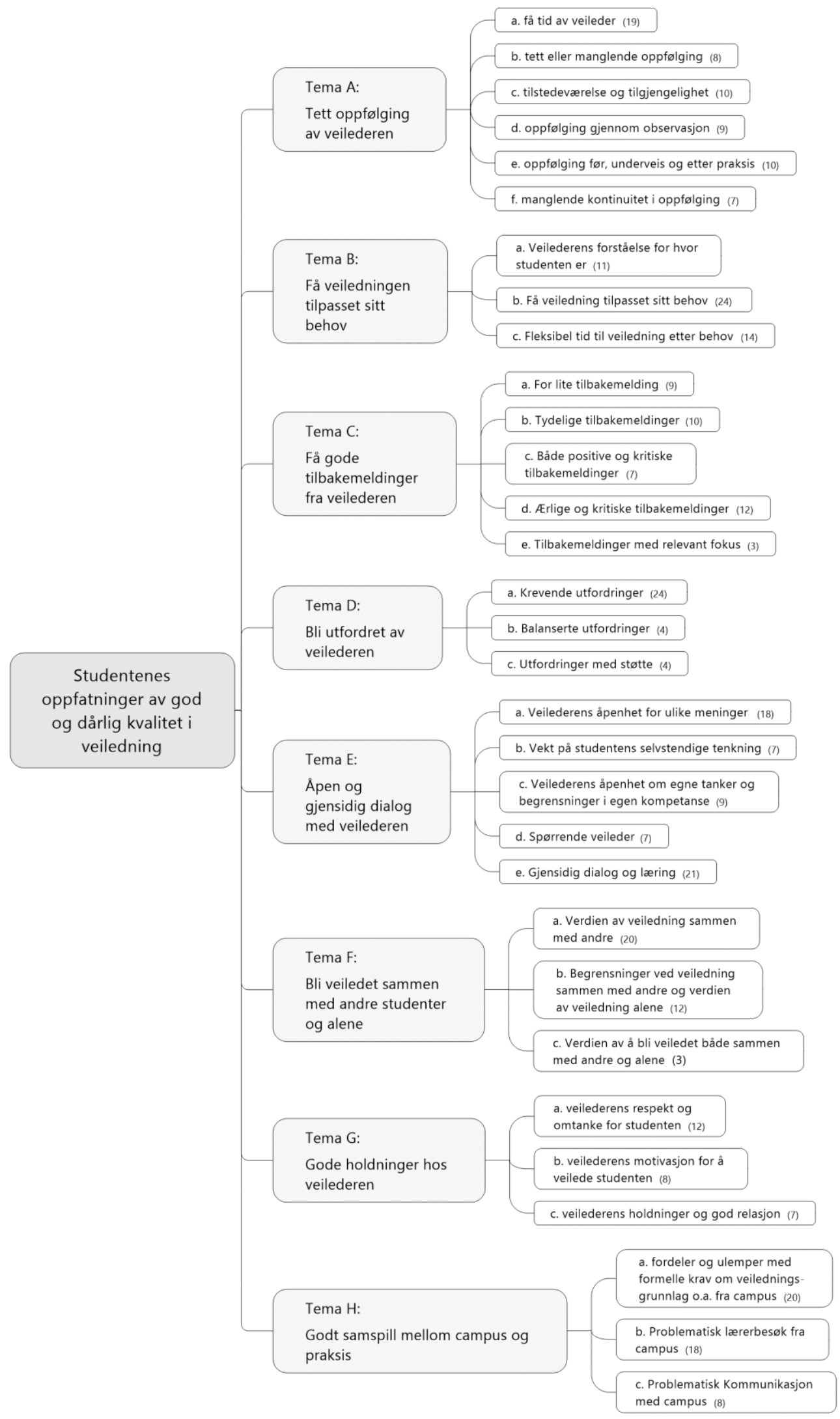

Figur 1. Åtte sentrale temaer om god og dårlig praksisveiledning, sett ut fra barnehagelærerstudenters perspektiv (antall koder angitt ift. deltemaer). 


\section{Analyse: Studentenes oppfatning av god og dårlig kvalitet i praksisveiledning}

Åtte temaer om kvalitet var særlig fremtredende i fokusgruppeintervjuene (jf. figur 1). Temaene omfatter studentenes kontrastfylte erfaringer av god og dårlig kvalitet i praksisveiledningen, og alle fokusgrupper snakket om samtlige temaer.

\section{Tema A: Tett oppfølging av veilederen}

En fremtredende oppfatning var at studentene ville bli fulgt tett opp av veilederen. En del studenter fremhever positive opplevelser av å bli viet tid og oppmerksomhet, mens andre opplevde at veilederen hadde for lite tid til dem.

Student A: Min veileder ... var også veldig nøye på at vi hadde alle veiledningene. Vi gikk ikke glipp av noe ... Selv om vi kanskje ikke fikk det til på den dagen ..., så tok vi det neste dag.

Student B: Det var litt verre hos oss. Vi var to studenter, og hun hadde masse ting på avdelingen. Så det ble veldig skyndte seg å gå igjennom, ... Du fikk ikke tid. ... Jeg føler det at jeg ikke får tatt opp de tingene jeg lurer på ...

Studenter gir også mer generelt uttrykk for variabel oppfølging gjennom uttalelser som: Min veileder er ... kanskje litt for avslappet, eller: Jeg har hatt en veileder som fortalte meg at jeg ikke trengte veiledning. To studenter uttrykker kontrastfylte opplevelser av oppfølgingen:

Student $A:$... hun var veldig flink til å se situasjoner ... hun kom til oss.

Student B: ... Slikt opplevde ikke jeg noe av. Det skulle vi ha hatt mer av og at de kom til oss etter en situasjon.

... I barnehagen så var det veldig sånn «gjør det du selv vil» ... hun kunne vært flinkere på å ta kontakt.

Studentene beskriver veilederne som mer eller mindre tilgjengelig og tilstedeværende som observat $\varnothing$ rer: Min veileder var som regel veldig mye borte. ... Hun kan ikke gi meg tilbakemelding på hvordan jeg er med ungene hvis hun aldri har sett meg. Studenter forteller videre at veiledere i varierende grad vektlegger veiledning $f \varnothing r$, underveis og etter situasjoner i praksis. Dessuten følger veiledere i ulik grad opp tråden fra veiledning til veiledning og problemstillinger som utsettes glemmes tidvis.

\section{Tema B: Få veiledning tilpasset sitt behov}

Et annet tema i intervjuene er betydningen av at veilederen klarer å forstå hvor studenten er, med hensyn til opplevelser, erfaringsbakgrunn, nivå og personlighet - og at veiledningen tilpasses til dette. Spesielt fremheves utfordringen i å forstå uerfarne studenter:

Det kan jo være en utfordring (å) få en veileder som har jobbet i 25 år og kanskje har mistet litt den forståelsen for hvordan det er å være helt ny. ... Det å ha en veileder som viser forståelse for at du ikke vet hva det går ut på, det er veldig bra.

Studentene har svært varierte opplevelser av veilederens evne til å forstå dem, noe som gjenspeiles i en meningsutveksling mellom to studenter:

Student A: De kan kanskje ta det litt for gitt sånne småting som jeg kanskje ikke har tenkt på, fordi jeg ikke har så mye erfaring med å jobbe i barnehage. ... «Så du ikke det i den situasjonen? Nei, jeg har aldri erfart det ...». Det kan være noe de har opplevd over tid, mens jeg som er ny klarer ikke å se den sammenhengen. ...

Student B: Det var det som var så bra med praksislæreren jeg hadde $\mathrm{i}$ år, fordi hun tok etter det utgangspunktet jeg hadde.

I intervjuene snakker studentene i tråd med dette om hvor avgjørende det er å tilpasse veiledningen til studentens nivå og personlighet mv. Det uttrykkes mange positive opplevelser av dette: Jeg kom på en avdeling med en som ikke hadde jobbet i barnehage før, mens jeg hadde jobbet i barnehage. Da fikk vi forskjellige utfordringer. Studentenes ønsker dreier seg for eksempel om at veilederen kan veilede på ulike måter, og mange vil påvirke hvordan veiledningen gjennomføres: Min praksisveileder sa at det var ulike måter å legge opp samtalen på og at det var opp til meg som student og si hvordan jeg ville ha det. ... Jeg 
syntes hun var flink der. Andre har mer negative opplevelser i dette henseendet: Jeg skulle ønske at veilederen min kunne se hva jeg ønsket å bli veiledet på.

Mange studenter fremhevet det også som verdifullt at veilederen tilpasser tidsbruken etter varierende behov, og de formidler kontrastfylte opplevelser av dette:

Student A: Hvis man kommer inn i en god diskusjon og på en måte får veldig naturlig fin flyt i samtalen ... at ikke klokka skal være så bestemmende, at nå må vi avslutte. At man kanskje må beregne litt slingringsmonn. Student B: Men jeg føler at det er veldig klokkestyrt ... alt. Nå er klokka 10, da tar vi det opp neste gang ... Og så blir det glemt. ... Men det er veldig forskjellig fra veileder til veileder.

Student $C$ : I vår barnehage, der tenker de ikke tid i hele tatt. De begrenser ikke tiden. Vi kan enten sitte den tiden vi skal eller ..., så er vi ferdig.

\section{Tema C: Få gode tilbakemeldinger fra veilederen}

Et tredje sentralt aspekt av kvalitet var betydningen av å få gode tilbakemeldinger fra veilederen, og studentene har svært variable erfaringer med dette. For eksempel opplever flere studenter å ha fått for lite tilbakemelding fra sin veileder:

Student A: Det var veldig sjeldent at hun sa «det du gjorde der var bra eller det var kanskje ikke så bra.» ... Siste uka så var jeg veldig spent på hva hun kom til å skrive på sluttvurderingen, fordi jeg visste ikke hva hun syntes. ...

Student B: Det verste som kan skje er jo hvis det står noe på den sluttevalueringen som du ikke vet om. ... Da

... raser det sammen og jeg forstår ingenting. ...

Sitatene ovenfor berører også andre verdsatte kvaliteter ved tilbakemeldingene som kommenteres nedenfor. Flere studenter fremhever at de kan være usikker på tilbakemeldingene og at veilederen bør kommunisere tydelig:

Det er veldig viktig at veilederen min er veldig tydelig og sier hva som er bra eller hva som det må jobbes mer med. ... At ikke jeg sitter og er usikker på om det jeg sier er helt på jordet ... jeg har opplevd å få tilbakemeldinger underveis, at veileder sier helt konkret «dette her er jo kjempebra».

Studentene ser det også som viktig å få kritiske og positive tilbakemeldinger, og at det er avgjørende at positive og kritiske tilbakemeldinger balanseres. En student fremhevet at kritiske tilbakemeldinger burde bli fulgt opp av positive bekreftelser når hun utvikler seg: Jeg synes det har vært veldig nyttig at de kommer tilbake til meg når de har sett at jeg har endret meg.

Flere fremhever at tilbakemeldingene kan bli for overfladiske og ukritiske, og at en til og med fornemmer at veilederen holder tilbake oppfatninger: Man blir så forsiktig, alt er så bra, du er så flink. Men det er jo ikke det man lærer av. I tillegg nevner enkelte at de savner tilbakemeldinger med mer relevant fokus.

\section{Tema D: Bli utfordret av veilederen}

En annen sentral side ved studentenes perspektiv på kvalitet er at de ønsker å få (mer) krevende utfordringer:

Student A: Det skulle jo bare mangle at man blir pushet litt. ... Men det virket på meg som om de er litt forsiktig på det. Litt sånn for snille på det.

Student B: Det var det jeg følte min veileder sviktet på i år, vi fikk aldri noen utfordringer.

Studentene verdsetter eller etterlyser for det første å få møte utfordrende situasjoner i praksis, å få tillit og få prøve seg frem i ulike situasjoner. En student sier for eksempel at det er viktig at veilederne er åpne for at vi får prøve selv i en vanskelig situasjon med unger. For det andre dreier uttalelsene seg om å bli utfordret i veiledningssamtalene, gjennom å møte krav om faglighet, teori, begrunnelser, samt kritisk og mer dyptgående tenkning: Du får bare kommentarer. Du får ikke utdypet noe, det blir bare overfladisk. Veileder burde grave mer...

Studenter kommenterer bare unntaksvis at de har fått for store utfordringer, og da dreier dette seg om at kritiske utfordringer ikke har vært balansert i forhold til positive momenter eller at studenten som 
møter kritikk ikke opplever seg støttet av veilederen: Det er veldig stor forskjell fra veileder til veileder noen er steinharde på det. Noen av studentene fremhever i tråd med dette at det er viktig at veilederen balanserer hva som er passende utfordringer og at veilederen gir praktisk og emosjonell støtte når studentene utfordres.

\section{Tema E: Åpen dialog og gjensidig læring}

Studentene snakker også mye om verdien av at veilederen er åpen i forhold til ulike måter å tenke, være og arbeide på. Spesielt ses det som avgjørende at veilederen viser åpenhet for ulike meninger, og flere studenter opplever dette som en svakhet: Det føltes litt som ... at de hadde liksom bestemt en retning som de tenkte i. Det å få det frem, det syntes jeg var litt vanskelig. Videre nevnes at studentens sårbare posisjon gjør det vanskelig med en lite åpen veileder: Man er jo alltid litt redd for å si ifra til praksislærer. ... Enkelte er jo ikke så flinke til å ta til seg konstruktiv kritikk ... Andre fremhever åpenhet som en særlig styrke ved sin veileder: ... så begynte hun å tenke over det ... vi kunne snakke om det og ... være uenig om ting ... og så argumenterte vi om de ulike sidene ved det. En annen student fortalte om en svært positiv opplevelse når hun hadde observert noe problematisk på avdelingen:

Og da syntes hun det var bra at jeg sa det og at hun ville ta det videre. ... Det å ta det videre var veldig godt

for meg, hun tok meg på alvor. ... At det er faktisk greit å komme med innspill.

Studenter verdsetter også at veileder understøtter studentens selvstendige tenkning i praksis og veiledningssamtaler: Man må tenke igjennom selv også, hva er det man kan gjøre? Det skaper grunnlag for en god diskusjon med veileder. Dette innebærer også å forstå studentens læring som en selvstendig prosess: Vi adopterer den kunnskapen som hun har gitt oss på vår måte.

Flere studenter fremhever også at veilederen bør være åpen om hvordan de selv tenker, og noen nevner at det kan være et problem at veilederen holder tilbake sin mening: ... du kan se ... at veileder reagerer på det du sier og ikke er enig ... og at de egentlig sitter og bobler. Da kan man jo bli utrygg. Da er det bedre hvis de sier det de tenker. Det nevnes videre som positivt at veilederen er åpen om hva de ikke selv kan.

Da sa hun at hun visste ikke ennå ... og det var veldig vanskelig. Og det var så godt å høre at de er ikke ferdig utlært de heller. ... Da kunne vi sammen prøve å finne måter. ... Da var det ikke sånn at hun svever på en stor sky over meg ... at hun vet alle svarene ...

Svært mange studenter fremhever dialog og gjensidighet i læringsprosessen som en viktig kvalitet. Noen studenter har hatt negative opplevelser av veiledning med monologisk eller belærende preg: Jeg har hatt en veileder som pratet så ufattelig mye ... fikk ikke sagt noe selv. En annen sier: Det tenker jeg er veldig viktig: Ikke (å) bli belært om noe. Vi er ... der for å lære, men vi har jo noe å si i saken vi òg. Isteden ønsker disse studentene mer dialog:

Det kan være greit at de kommer med opplysninger og så kan du komme inn etterhvert. Da vil du skape en dialog, ... sette de ulike erfaringene opp mot hverandre, da er man jevn.

Flere studenter uttrykte i tråd med dette et ideal om at begge kan lære gjennom veiledningen, og flere fremhever det som positivt at veiledere sier at de lærer av å veilede studenten: Man lærer av hverandre hele tiden. For meg er det viktig at veilederne tenker litt i de banene også. En student forteller om en veileder som trakk idealet om gjensidighet særlig langt:

Vi kjørte en omvendt veiledning der han kom med en case til meg som han slet med. ... Det lærte jeg mye av. Han fikk frem nye måter og se det på, og det gjorde jeg òg.

\section{Tema F: Bli veiledet sammen med andre studenter og alene}

Studentene utrykker positive vurderinger av å ha praksis sammen med en student i samme barnehage og å bli veiledet i grupper. Det fremheves for eksempel at dette gir god mulighet for rikere refleksjon og læring: Man merker at det er en annen hjerne der, kanskje den personen gjør seg refleksjoner som du ikke har tenkt på. Det fremheves at to studenter i praksis bidrar til flere perspektiver: Det er jo ikke alltid vi er 
helt enig, men det er jo sånn det skal være. (Man) får større perspektiv på ting. Dessuten kan flere studenter i praksis og veiledning bidra til at studenten opplever trygghet:

Hvis du bare tenker «det er feil, det er feil», så kan man ta det opp hvis det er noe som plager en skikkelig. ...

Vi hjalp hverandre når vi var usikre.

Studenter som har hatt praksis alene i en barnehage kan se dette som en utfordring: Jeg kjenner at det hadde vært greit å ha en som man kunne diskutere litt med ... Flere studenter fremhever likevel at de har behov for individuell veiledning, og at gruppeveiledning og praksis sammen med en eller flere studenter også har ulemper. For eksempel kan studenter vegre seg mot å si imot andre studenter, studenter kan få ujevn oppmerksomhet i veiledningen, veiledningen kan ta lang tid og to studenter på en liten avdeling kan gå i veien for hverandre og hemme involvering med ansatte. I forlengelsen av dette oppfatter flere at både individuell veiledning og gruppeveiledning har styrker og svakheter som utfyller hverandre: Gruppeveiledningen var bra, mens det hadde vært greit å være alene for de mer personlige tingene.

\section{Tema G: Gode holdninger hos veilederen}

Studentene vektlegger også veilederens uttrykte holdninger. Spesielt fremheves det som viktig at veilederen viser omtanke og respekt for studenten. Noen fremhever positive mens andre har negative opplevelser: Jeg vet at det var studenter nå i klassen som opplevde at praksislærer ikke brydde seg om dem. Det vurderes videre som negativt at studenten kan oppleve å bli sett ned på eller å bare være student. Motsatt nevnes positive formuleringer som å bli tatt på alvor, bli hørt og møtt med interesse:

Det er viktig at jeg blir tatt seriøst, å få bekreftelse på det jeg sier. At jeg føler at de synes det er viktig, det jeg sier. Det er jo viktig for meg.

En annen side ved veilederens holdninger er hvorvidt studenten opplever at veilederen er motivert for å veilede studenten. Her har enkelte studenter erfart svekket utbytte av veiledningen: ... så er de sånn halvlunkne ... går ikke ordentlig inn for det - da mister du motivasjonen.

En annen student problematiserer også veileders uttrykk for positive holdninger: De fleste sier jo at de er så glade for å få studenter etc. ... men så er de jo egentlig ikke det. Andre forteller om svært positive opplevelser av veilederens holdninger, for eksempel gjennom at veilederen gledet seg til å ha studenter, samt at veilederen eller barnehagen hadde utbytte av å ha studenter i praksis: Hun sa ... at hun var heldig som fikk studenter inn, fordi hun ønsket tilbakemeldinger på ting som jeg så ...

Flere studenter kommenterer også sammenhengen mellom veilederens holdninger og det å utvikle god relasjon, kjemi, komme overens eller ha gjensidig tillit mellom student og veileder: Jeg tror ikke man kan ha en god veiledning uten at man har tillit til og respekt for hverandre.

\section{Tema H: Godt samspill mellom praksis og campus}

Studenter var også opptatt av hvordan samspillet med campus påvirket veiledningens kvalitet. For det første omtales fordeler og ulemper med formelle krav til praksisveiledningen fra campus. Enkelte nevner at detaljerte krav kan hemme fokus på studentenes personlige utviklingsmål. Mer spesifikt uttrykkes varierte opplevelser av planens krav om bruk av skriftlig veiledningsgrunnlag. Det ses verdi $i$ at veiledningsgrunnlag kan bidra til forberedelse og sikre fokus, samtidig som det også kan hindre at viktige temaer av mer spontan art tas opp i veiledningen. Noen studenter fremhever derfor at veiledningsgrunnlag bør brukes fleksibelt.

For det andre uttrykker mange studenter misnøye med praksisbesøk av faglærer fra campus. Innvendingene dreide seg om uklart mål for, samt manglende forberedelser til og prosedyrer for besøket:

Når vi hadde besøk av læreren fra Universitetet. Den var jeg ikke så fornøyd med. Da visste vi ikke hva vi skulle gjøre, vi skjønte ingenting, praksislæreren hadde ikke fått info. ... «Hva har dere gjort?» ... og så lurte vi på om hun ville være med og se på (en aktivitet), men det ville hun ikke fordi hun var redd for å være et uromoment for ungene. Så vi skjønte egentlig ikke hvorfor hun kom eller hva hun skulle ta opp med oss.

Flere studenter nevner at en bør ha samtaler med læreren fra campus både alene og sammen med praksisveilederen, og at det oppleves vanskelig å ta initiativ til en alene-samtale selv: Da stilte lærer 
spørsmål(et) "har dere lyst til å ta opp noe som dere vil at veileder ikke skal høre på?», og da satt jo veileder der. ... Hva skal du si da?

Andre forteller også at veiledningens kvalitet har blitt svekket av uklare retningslinjer og kommunikasjon med campus. Eksempelvis nevnes at praksisveilederens usikkerhet $i$ tolkning av retningslinjer virker negativt og at en har opplevd det som vanskelig å få svar fra campus på spørsmål om dette.

\section{Forskjeller mellom årskull}

Det kan sees tendenser til at ulike aspekter av kvalitet vektlegges ulikt på ulike studieår: Temaene «tett oppfølging av veilederen» (A) og "bli veiledet alene og sammen med andre» (F) har en viss overvekt av førsteårsstudenter; «veiledning tilpasset sitt behov» (B) og «bli utfordret av veilederen» (D) har noe overvekt av andreårsstudenter; «gode holdninger» (G) og «godt samspill mellom campus og praksis» (H) har overvekt av første- og tredjeårsstudenter, mens temaene "gode tilbakemeldinger» (C) samt «åpen og gjensidig dialog (E) er jevnt representert på tvers av årskull. Datamaterialets art og omfang gir et for begrenset grunnlag for komparativ analyse, men forskjellene gir et interessant utgangspunkt for videre forskning.

\section{Avsluttende diskusjon}

Temaene og deltemaene viser at studentenes oppfatninger av kvalitet er mangefasettert, kan forstås som prosesskvalitet og har likhetstrekk med tidligere forskning på barnehagestudenters oppfatninger. Imidlertid avdekket ingen tidligere enkeltundersøkelser samme bredde i kvalitetsaspekter som denne undersøkelsen, noe som kan ha sammenheng med studiens fokusgruppetilnærming. Tydeligst overenstemmelse finnes for det første gjennom studentenes oppfatning av at veilederen bør tilpasse veiledningen til den enkelte student (tema B og 5 jf. internasjonal forskningsgjennomgang), og for det andre i betydningen av gode tilbakemeldinger ( $C$ og 4). Det er også overensstemmelse mellom positiv vurdering av å bli veiledet sammen med andre studenter ( $F$ og 7$)$.

Andre temaer viser betydelig overensstemmelse, men involverer flere nyanser. Internasjonale studiers fremheving av relasjon (1) korresponderer ikke direkte med et enkelt hovedtema i denne unders $\varnothing$ kelsen, men dekkes langt på vei av temaet "gode holdninger» hos veilederen ( $G$, spesielt deltema $\mathrm{a} / \mathrm{c}$ ). Relasjon er dessuten en så vid kategori at den favner flere andre tematiske funn $\mathrm{i}$ denne unders $\varnothing$ kelsen (spesielt A, B, C og E). Det samme gjelder betydningen av emosjonell og praktisk st $\varnothing$ tte fra veilederen (3), som er sentralt i flere andre temaer (A, C, Dc og Ga). Videre overlapper temaet «veilederens $\varnothing$ vrige egenskaper» (6) temaet "gode holdninger hos veilederne» (G). Enkelte internasjonale unders $\emptyset$ kelser fremhever også godt samspill mellom campus og praksis $(H)$.

Noen av funnene i denne undersøkelsen avviker mer fra tidligere forskning. Dette gjelder særlig betydningen av å bli utfordret av veilederen (D), som ikke tilsvarer funn fra de internasjonale studiene. En relatert forskjell kan også sees om en ser nærmere på deltemaene under hovedtemaet "gode tilbakemeldinger» ( $\mathrm{Cc} / \mathrm{d})$, der studentene i denne unders $\varnothing$ kelsen i noe sterkere grad vektlegger kritiske eller utfordrende tilbakemeldinger. Dessuten verdsetter studentene i denne undersøkelsen tydeligere tettere oppfølging av veilederen (A). En annen forskjell er at de verdsetter tydeligere åpen og gjensidig dialog med veilederen (E), selv om verdsettingen av selvstendighet $\mathrm{i}$ internasjonale studier (2) dels berører åpenhet for utvikle egen praksis. I flere internasjonale undersøkelser vektlegges dessuten betydningen av pedagogisk selvstendighet, noe som ikke er like tydelig i denne norske undersøkelsen (delvis Da og Eb).

Studentenes oppfatninger av kvalitet gir ingen entydig preferanse for én av de tre veiledningstradisjonene som ble omtalt innledningsvis. Det er derimot rimelig å hevde at studentenes perspektiv overskrider tradisjonene, idet de verdsetter ulike aspekter av kvalitet som vektlegges innenfor hver av tradisjonene. Det er problematisk å sammenligne veiledningstradisjonenes karakteristiske kvaliteter presist, spesielt fordi veiledning på sosiokulturelt grunnlag ikke kan avgrenses til én hovedkilde, slik de to $\varnothing$ vrige tradisjonene kan. Likevel nevnes noen tendenser: 
Sentrale kvaliteter i mesterlæretradisjonen verdsettes for eksempel av studentene gjennom temaet «tett oppfølging av veilederen» (A), vekt på tydelige tilbakemeldinger på praktisk handling (C), og i noen grad å bli utfordret (D). Refleksjon over handling korresponderer delvis med mange temaer, og bildet varierer avhengig av om man vektlegger det humanistiske eller diskursive dialogidealet innenfor tradisjonen. Det humanistiske dialogidealet er særlig på linje med studentenes verdsetting av å få veiledningen tilpasset sitt behov (B), gode veileder-holdninger (G) og gode holdninger hos veilederen (E). Veiledning på sosiokulturelt grunnlag korresponderer særlig med å få gode tilbakemeldinger fra veilederen (C), bli utfordret av veilederen (D) og å bli veiledet sammen med andre (dels F).

Studentenes vekt på verdien av åpen dialog og gjensidig læring (E) korresponderer sterkt med idealer innenfor både veiledning på sosiokulturelt grunnlag og refleksjon over handling - og innenfor sistnevnte tradisjon er temaet i sterkest overensstemmelse med det diskursive dialogidealet.

Samlet sett verdsetter barnehagestudentene i denne undersøkelsen, i likhet med internasjonale undersøkelser, kvaliteter som særlig kjennetegner dominerende tradisjoner som refleksjon over handling og veiledning på sosiokulturelt grunnlag. Det er imidlertid verdt å merke seg at disse i høyere grad enn studenter i internasjonale studier verdsetter veiledere som følger studenten tettere opp og utfordrer studenten sterkere og mer kritisk. Slike kvaliteter kan dels knyttes til mesterlæretradisjonen og dels det diskursive dialogidealet (innenfor refleksjon over handling). En mulig samfunnsmessig forklaring på forskjellen, kan være at nordiske land er av de mest likhetsorienterte samfunn vi kjenner til i verdenshistorien (f.eks. Lambie, 2014), og norske studenters mulighet for innflytelse i utdanningene ansees som særlig store (Kunnskapsdepartementet, 2017, s. 42). Dette kan bidra til å forklare det sterke gjennomslaget disse veiledningstradisjonene har hatt i Norden de siste tiårene, og at det humanistiske dialogidealet (innenfor refleksjon over handling) muligens har hatt aller sterkest gjennomslag. En interessant hypotese er at dette har bidratt til en mer indirekte og forsiktig veilederrolle i Norden enn $\mathrm{i}$ andre vestlige land. Studenter i undersøkelsen gir i alle fall uttrykk for at noen veiledere kan bli for tilbaketrukket. Motsvarende kan en hypotese være at veiledning i vestlige land som ikke har vært like sterkt influert av slike veiledningstradisjoner er mer tradisjonell og asymmetrisk, idet praksisveiledning tradisjonelt har vært preget av begrenset frihet (Macy \& Squires, 2009). Dette kan forklare at studenter i internasjonale studier er noe mer opptatt av muligheter til pedagogisk frihet (2) enn studentene i denne undersøkelsen, i det de norske studentene muligens har større frihet.

Undersøkelsen gir i alle fall grunn til å fokusere på veilederens kompetanse og betydningen av veilederutdanning. Det fordrer en kompetent veileder for å kunne samarbeide godt med studentene, ut fra det komplekse bildet som tegnes av deres perspektiv på praksisveiledningens kvalitet. De åtte temaene peker også mot innhold som er viktig å fokusere på i veilederutdanning og barnehagelærerutdanning. Studien gir ikke minst grunn til å overskride det kvalitetsperspektivet én enkelt veiledningstradisjon representerer.

Studiens st $\varnothing$ rrelse gir ikke grunnlag for å generalisere om norske barnehagestudenters oppfatninger av kvalitet i praksisveiledning. Fokusgruppedata gir heller ikke grunnlag for å rangere presist hvor viktig de ulike temaene er for studentene i undersøkelsen (Guest m.fl., 2012). Studien gir likevel et relevant bredspektret bilde av studenters oppfatninger om god og dårlig praksisveiledning, som kan unders $\varnothing$ kes nærmere i større unders $\varnothing$ kelser. 


\section{Referanser}

Barbour, R. (2007). Doing Focus Groups. London: Sage.

Beck, C. \& Kosnik, C. (2002). Components of a Good Practicum Placement: Student Teacher Perceptions Teacher Education Quarterly, 29(2), 81-98. doi: http://www.jstor.org/stable/23478294

Bjerkestrand, M., Fiske, J., Hernes, L., Samuelsson, I. P., Sand, S., Simonsen, B., Stenersen, B., Storjord, M. H. \& Ullmann, R. (2016). Barnehagelærarutdanninga. Tilbakevendande utfordringar og uprøvde mulegheiter. Rapport frå Følgjegruppa for barnehagelærarutdanning til Kunnskapsdepartementet. Rapport nr.3 ISBN: 978-82- 7709-212-6. Bergen: Høgskolen i Bergen. Hentet fra http://blu.hib.no/wp-content/uploads/2016/10/Rapport-3.pdf

Bjerkestrand, M., Fiske, J., Hernes, L., Samuelsson, I. P., Sand, S., Simonsen, B., Stenersen, B., Storjord, M. H. \& Ullmann, R. (2017). Barnehagelærarutdanninga. Styrker, svakheiter og gjenstridige utfordringar. Sluttrapport frå Følgjegruppa for barnehagelærarutdanning til Kunnskapsdepartementet. Rapport nr. 5 ISBN: 978-82-7709-215-7. Bergen: Høgskolen i Bergen. Hentet fra https://www.regjeringen.no/contentassets/0efc6554255647b1b138e4a2507f0c17/sluttrapport-frafolgjegruppa-for-barnehagelararutdanning.pdf

Bjerkholt, E. (2017). Profesjonsveiledning. Fra praktisk virksomhet til teoretisk felt. Oslo: Cappelen Damm Akademisk.

Bjørndal, C. R. P. (2008). Bak veiledningens dør. Symmetri og asymmetri i veiledningssamtaler. Dr.polit. avhandling (Doktoravhandling, Universitetet i Troms $\varnothing$ ). Hentet fra http://hdl.handle.net/10037/7092

Braun, V. \& Clarke, V. (2006). Using thematic analysis in psychology. Qualitative Research in Psychology, 3(2), 77-101. https://doi.org/10.1191/1478088706qp063oa

Bullough, R. V., Young, J., Erickson, L., Birrell, J. R., Clark, D. C., Egan, M. W., Berrie, C. F., Hales, V. \& Smith, G. (2002). Rethinking Field Experience: Partnership Teaching versus Single-Placement Teaching. Journal of Teacher Education, 53(1), 68-80. https://doi.org/10.1177/0022487102053001007

Caires, S., Almeida, L. S. \& Martins, C. (2009). The Socioemotional Experiences of Student Teachers During Practicum: A Case of Reality Shock? Journal of Educational Research, 103(1), 17-27. https://doi.org/10.1080/00220670903228611

Campbell-Evans, G. \& Maloney, C. (1997). An Alternative Practicum Curriculum: exploring roles and relationships. Asia-Pacific Journal of Teacher Education, 25(1), 35-52. https://doi.org/10.1080/1359866970250104

Charmaz, K. (2006). Constructing grounded theory: a practical guide through qualitative analysis. London: Sage.

Dahler-Larsen, P. (2013). Kvalitetens beskaffenhet og den svage tænkning. I Y. Nordkvelle, T. Fossland \& G. Netteland (Red.), Kvalitet i fleksibel høyere utdanning. Nordiske perspektiver (s. 29-40). Trondheim: Akademika forlag.

Eik, L. T. (2014). Ny i profesjonen. En observasjons- og intervjustudie av førskolelæreres videre kvalifisering det første året i yrket (Doktorgradsavhandling, Universitetet i Oslo). Hentet fra http://urn.nb.no/URN:NBN:no-48412

Elken, M. (2007). QU trends 1995-2006 Literature overview. Oslo: University of Oslo.

Field, H. (2002). Developmentally Appropriate Practicum Supervision: Perceptions of Students and Supervisors. Paper presented at the Annual Meeting of the Association of Childhood Education International, San Diego, CA, April 3-6, 2002. Hentet fra https://files.eric.ed.gov/fulltext/ED468735.pdf 
Fimreite, H. \& Fossøy, I. (2018). Kunnskap i endring: Kollegaveiledning som innfallsvinkel til utvikling av lærande barnehagar. Nordic Studies in Education 38(01), 52-66. Doi: 10.18261/issn.1891-5949-201801-05

Forskrift om rammeplan for barnehagelæreutdanning. (2012). Forskrift om rammeplan for barnehagelæreutdanning (FOR-2012-06-04-475). Hentet fra https://lovdata.no/dokument/SF/forskrift/2012-06-04-475

Gjems, L. (2007). Meningsskaping i veiledning. Bergen: Fagbokforlaget.

Han, H. S. \& Damjanovic, V. (2014). Preservice Teacher Learning within a Kindergarten Internship: Insights for Early Childhood Teacher Educators. The Teacher Educator, 49(4), 284-304. https://doi.org/10.1080/08878730.2014.943622

Harvey, L. (2006). Understanding quality. EUA Bologna Handbook: Making Bologna work, 1(1), 1-29. Hentet fra http://www.qualityresearchinternational.com/Harvey\%20papers/Harvey\%202006\%20Understandin g\%20quality.pdf

Hatlevik, I. K. R. (2016). Hvordan utvikle og kontrollere prosesskvalitet?. Uniped: Tidsskrift for universitets- og høgskolepedagogikk, 39(3), s. 195-210. doi: 10.18261/issn.1893-8981-2016-03-02

Hjort, M. \& Pramling, N. (2014). Den blivande förskollärarens formering; en studie av verksamhetsförlagda handledningssamtal, argumentationstraditioner och metaforik. Nordisk Barnehageforskning 7(18). https://doi.org/10.7577/nbf.610

Juul, J. J. (2015). Placement supervision of pedagogue students in Denmark: the role of university colleges and early childhood centres. Early Years, 35(2), s. 154-167. https://doi.org/10.1080/09575146.2015.1024616

Kim, T. \& Danforth, S. (2012). Non-authorative approach to supervision of student teachers: Cooperating teachers' conceptual metaphors. Journal of Education for Teaching: International research and pedagogy, 38(1), 67-82. http://www.tandfonline.com/doi/full/10.1080/02607476.2012.643658

Kromrey, J. \& Wynn, M. J. (1999). Paired Peer Placement with Peer Coaching in Early Field Experiences: Results of a Four-Year Study. Teacher Education Quarterly, 26(1), 21-38.

Kunnskapsdepartementet. (2017). Kultur for kvalitet i høyere utdanning (Meld. St. 16 (2016-2017)). Hentet fra https://www.regjeringen.no/contentassets/aee30e4b7d3241d5bd89db69fe38f7ba/no/pdfs/stm201 620170016000dddpdfs.pdf

Kvale, S., Nielsen, K. \& Jensen, K. (1999). Mesterlære: Læring som sosial praksis. Oslo: Ad Notam Gyldendal.

Lambie, J. (2014). How to be critically open-minded: a psychological and historical analysis. Basingstoke, Hampshire, UK: Palgrave Macmillan.

Lauvås, P. \& Handal, G. (2014). Veiledning og praktisk yrkesteori (3. utg.). Oslo: Cappelen Damm Akademisk.

Ledoux, M. W., Yoder, N., Hanes, B. \& McHenry, N. (2008). Teacher candidate training in high quality day care centres and in lower socioeconomic settings. I P. G. Grotewell \& Y. R. Burton (Red.), Early childhood education: Issues and developments (s. 7-22). New York: Nova Science Publishers.

Macy, M. \& Squires, J. (2009). L'arte D'arrangiarsi: Evaluation of an Innovative Practice in a Preservice Practicum. Journal of Early Intervention, 31(4), 308-325. https://doi.org/10.1177/1053815109352585

Macy, M., Squires, J. K. \& Barton, E. E. (2009). Providing Optimal Opportunities: Structuring Practicum Experiences in Early Intervention and Early Childhood Special Education Preservice Programs. Topics in Early Childhood Special Education, 28(4), 209-218. https://doi.org/10.1177/0271121408327227 
Malderez, A., Hobson, A. J., Tracey, L. \& Kerr, K. (2007). Becoming a Student Teacher: Core Features of the Experience. European Journal of Teacher Education, 30(3), 225-248. https://doi.org/10.1080/02619760701486068

McCollum, J. A. \& Catlett, C. (1997). Designing Effective Personnel Preparation for Early Intervention: Theoretical Frameworks. I P. J. Winton, J. A. McCollum \& C. Catlett (Red.), Reforming Personnel Preparation in Early Intervention: Issues, Models, and Practical Strategies (s. 105-126). Baltimore: Paul H. Brookes Publishing Co.

McNay, M. \& Graham, R. (2007). Can cooperating teachers help student teachers develop a vision of education? The Teacher Educator, 42(3), 224-236. https://doi.org/10.1080/08878730709555404

Moody, J. (2009). Key elements in a positive practicum: insights from Australian post-primary preservice teachers. Irish Educational Studies, 28(2), 155-175. https://doi.org/10.1080/03323310902884219

Nicholson, S. \& Reifel, S. (2011). Sink or Swim: Child Care Teachers' Perceptions of Entry Training Experiences. Journal of Early Childhood Teacher Education, 32(1), 5-25. https://doi.org/10.1080/10901027.2010.547650

Oberhuemer, P. (2015). Seeking new cultures of cooperation: a cross-national analysis of workplacebased learning and mentoring practices in early years professional education/training. Early Years, 35(2),115-123. https://doi.org/10.1080/09575146.2015.1028218

Recchia, S. L. \& Puig, V. I. (2011). Challenges and Inspirations: Student Teachers' Experiences in Early Childhood Special Education Classrooms. Teacher Education and Special Education, 34(2), 133-151. https://doi.org/10.1177/0888406410387444

Rouse, L., Morrissey, A.-M. \& Rahimi, M. (2012). Problematic placement: pathways pre-service teachers' perspectives on their infant/toddler placement. Early Years, 32(1), 87-98. https://doi.org/10.1080/09575146.2011.610299

Shahid, M. S. \& Hussain, M. A. (2011). Expectations and Experiences of Pupil Teachers during Teaching Practice: Theoretical and Practical Implications. Procedia - Social and Behavioral Sciences, 29, 17331739. https://doi.org/10.1016/i.sbspro.2011.11.419

Skagen, K. (2013). I veiledningens landskap: Innføring i veiledning og rådgivning (2. utg.). Oslo: Cappelen Damm Akademisk.

Steinnes, G. S. (2014). Profesjonalitet under press? Ein studie av førskulelærarar si meistring av rolla i lys av kvalifiseringa til yrket og arbeidsdelinga med assistentane (Doktoravhandling, Høgskolen i Oslo og Akershus). Hentet fra http://hdl.handle.net/10642/2921

Søndenå, K. (2004). Kraftfull refleksjon i lærarutdanninga. Oslo: Abstrakt forlag.

Søndenå, K. (2007). Refleksjonen, dialogen og demokratiet. I T. Kroksmark \& K. Åberg (Red.), Veiledning i pedagogisk arbeid (s. 210-222). Bergen: Fagbokforlaget.

Turnbull, M. (2005). Student teacher professional agency in the practicum. Asia-Pacific Journal of Teacher Education, 33(2), 195-208. https://doi.org/10.1080/13598660500122116

Vallberg Roth, A.-C. (2014). Nordic Comparative Analysis of Guidelines for Quality and Content in Early Childhood Education. Tidsskrift for Nordisk Barnehageforskning, 8(1), 1-35. https://doi.org/10.7577/nbf.693

Van Schagen Johnson, A., La Paro, K. M. \& Crosby, D. A. (2017). Early Practicum Experiences: Preservice Early Childhood Students' Perceptions and Sense of Efficacy. Early Childhood Education Journal, 45(2), 229-236. http://dx.doi.org/10.1007/s10643-016-0771-4

Walsh, K. \& Elmslie, L. (2005). Practicum pairs: an alternative for first field experience in early childhood teacher education. Asia-Pacific Journal of Teacher Education, 33(1), 5-21. https://doi.org/10.1080/1359866052000341098 
Weasmer, J. \& Woods, A. M. (2003). The Role of the Host Teacher in the Student Teaching Experience. The Clearing House: A Journal of Educational Strategies, Issues and Ideas, 76(4), 174-177. https://doi.org/10.1080/00098650309601998

Wee, S.-J., Weber, E. K. \& Park, S. (2014). Early childhood practicum students' professional growth in the USA: areas of confidence and concern. International Journal of Early Years Education, 22(4), 409422. https://doi.org/10.1080/09669760.2014.911644

Wittek, L. \& Kvernbekk, T. (2011). On the Problems of Asking for a Definition of Quality in Education, Scandinavian Journal of Educational Research, 55(6), 671-684.

https://doi.org/10.1080/00313831.2011.594618

Worum, K. S. (2014). Veiledning, kunnskapssyn og danning. Norsk pedagogisk tidsskrift, 98(1), 26-35.

Worum, K. S. (2016). Spor av sammenhenger og brudd i kunnskapssyn i veiledning ved lærerutdanningen. Norsk pedagogisk tidsskrift, 100(2), 103-114.

$\emptyset$ degaard, E. E. \& Økland, M. S. (2015). Fortellinger fra praksis: Trøbbel, vendepunkt og stolthet. Bergen: Fagbokforlaget.

Ødegård, E. (2011). Nyutdannede pedagogiske lederes mestring og appropriering av barnehagens kulturelle redskaper: En kvalitativ studie av nyutdannede førskolelæreres kompetansebygging det første året i yrket (Doktoravhandling, Universitetet i Oslo). Hentet fra: http://hdl.handle.net/11250/2438207 